\title{
The Vascular Flora of the Cerrado in Emas National Park (Central Brazil): a Savanna Flora Summarized
}

\author{
Marco Antônio Batalha ${ }^{1}$ and Fernando Roberto Martins ${ }^{2}$ \\ ${ }^{1}$ Departamento de Botânica; Universidade Federal de São Carlos; marcobat@uol.com.br; C. P. 676; 13565-905; \\ São Carlos - SP - Brasil. ${ }^{2}$ Departamento de Botânica; Instituto de Biologia; Universidade Estadual de Campinas; \\ fmartins@unicamp.br; C.P.6109; 13083-970; Campinas-SP - Brasil
}

\begin{abstract}
The Brazilian cerrado may be divided in two main phytogeographic sectors: one characterized by Piptocarpha rotundifolia, in which the Emas National Park (ENP) is located, and other characterized by Curatella americana. We carried out a floristic survey in ENP, which allowed an assessment of the taxonomic composition, taxa size, and similarity with other sites for the ENP's vascular flora. We compared the ENP's flora with southeastern outlying cerrado sites, also in the Piptocarpha sector, and with general floristic patterns in the cerrado vegetation. The distribution of species per family in ENP was significantly different from that obtained for each component of the general cerrado flora. The herbaceous component was characterized by an overproportion of Myrtaceae and an underproportion of Orchidaceae and Lythraceae; and the woody component, by an overproportion of Myrtaceae and Nyctaginaceae. When compared with outlying cerrado sites, the ENP was quite distinct, not only at species level, but also at family level.
\end{abstract}

Key words: Cerrado, floristics, phytogeography, principal component analysis, savanna

\section{INTRODUCTION}

The Cerrado Domain is the second largest Brazilian phytogeographic province, occupying originally $23 \%$ of Brazil's land area (Ratter et al., 1997). As its name implies, in the Cerrado Domain, the cerrado vegetation prevails. The cerrado vegetation has several structural and physiognomic types, from grasslands to tall woodlands, but most of its physiognomies fit the definition of tropical savannas (Sarmiento, 1983). The cerrado core area covers the Brazilian Central Plateau, and outlying areas occur, for example, in the southeastern São Paulo State (Ratter et al., 1997). The cerrado was included among the hotspots for conservation in the world due to its high richness, high degree of endemism, and current conservation status (Fonseca et al., 2000). The cerrado vascular flora has an herbaceous and a woody component, which are antagonistic because both are heliophilous (Coutinho, 1990). Castro et al. (1999) and Ratter et al. (2003) compiled many floristic and quantitative surveys and listed 973 and 951 species, respectively, identified for the cerrado woody component. Based on taxonomic revisions, floristic surveys, and visits to herbaria, Batalha (2001) listed 2,856 species in the cerrado herbaceous component.

Castro (1994) recognized two major sectors in the whole Brazilian cerrado area, separated by an imaginary line from northeast to southwest crossing roughly the center of the Central

\footnotetext{
${ }^{*}$ Author for correspondence
} 
Brazilian Plateau. The sector south of this line is indicated by the presence of Piptocarpha rotundifolia (Less.) Baker (Asteraceae), while the sector north of this line, by the presence of Curatella americana L. (Dilleniaceae) (Fig. 1). Ratter et al. (1996; 2003) recognized six and seven phytogeographic groups, respectively, for the cerrado woody flora but did not discuss the occurrence of $P$. rotundifolia and $C$. americana as a major division of the cerrado phytogeographic sectors.

The Emas National Park (ENP) is located in the cerrado core region and is one of the largest and most important reserves representing this vegetation type (Fonseca et al., 2000). Recently, ENP was included by Unesco (2001) in the World Natural Heritage List as one of the most important sites containing flora, fauna, and key habitats that characterize the cerrado. We carried out a floristic survey in the cerrado of ENP (Batalha and Martins, 2002), which allowed an assessment of the taxonomic composition, taxa size, and similarity with other sites for the ENP's vascular flora.

The aim of this study was to compare the ENP's flora with southeastern outlying cerrado sites and with general floristic patterns in the cerrado vegetation. Both ENP and the southeastern outlying sites are in the Piptocarpha rotundifolia sector; whereas ENP is located in the northwestern extreme of this sector, the outlying sites are located in its southeastern extreme. We tried to answer the following questions: Is the distribution of species per family in the woody and herbaceous components in ENP different from those found by Castro et al. (1999) and Batalha (2001) for the whole cerrado? If so, which families characterize the ENP's woody and herbaceous components? Is there any species amongst the most constant woody species in cerrado sites (Ratter et al., 1996; 2003) that does not occur in ENP? Are there woody species in ENP's flora that should be included in the checklist elaborated by Castro et al. (1999)? Within the P. rotundifolia sector, are the southeastern outlying cerrado sites (Mantovani and Martins, 1993; Batalha et al., 1997; Batalha and Mantovani, 2000) more similar among themselves than to a core cerrado site, such as ENP? When compared with these southeastern outlying cerrado sites, which families characterize the ENP and which families characterize the outlying sites?

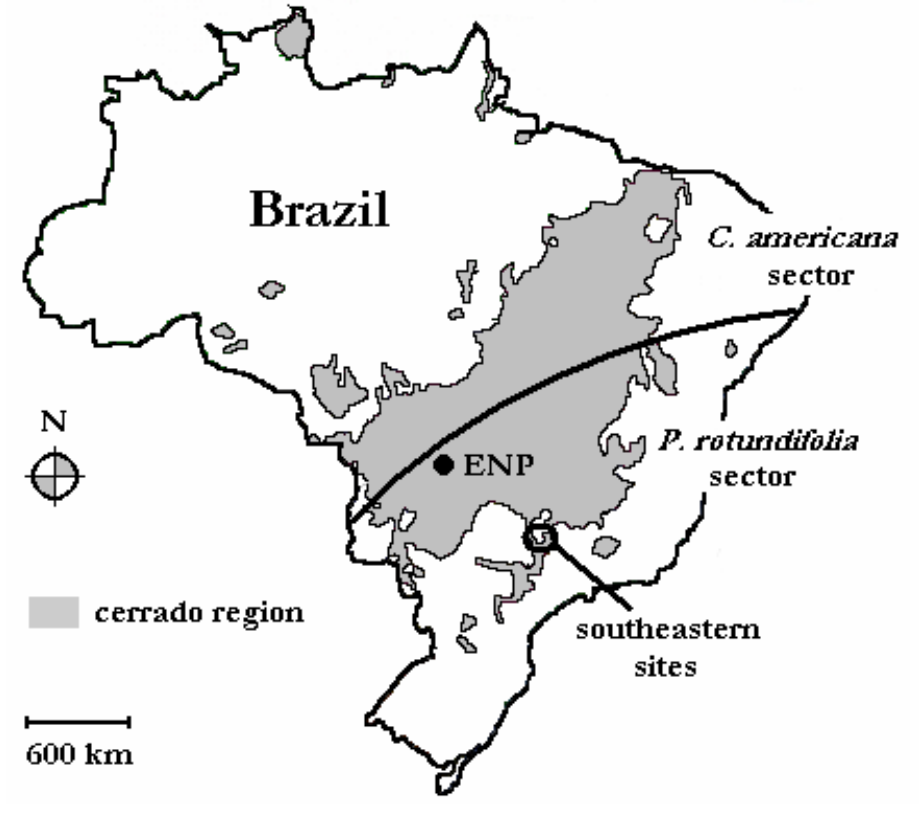

Figure 1 - Cerrado region and its two sectors, the Curatella americana and Piptocarpha rotundifolia sectors, with approximate locations of the Emas National Park (ENP) and southeastern sites (after Castro, 1994, modified). 


\section{MATERIAL AND METHODS}

The ENP is located in the Brazilian Central Plateau, in the cerrado core region, southwestern Goiás State $\left(17^{\circ} 49^{\prime}-18^{\circ} 28^{\prime} \mathrm{S}, 52^{\circ} 39^{\prime}-53^{\circ} 10^{\prime} \mathrm{W}\right)$. The park was created in 1961 with 132,941 ha. Regional climate is humid tropical, with wet summer and dry winter, and classified as Aw following Köppen (1931). Annual rainfall varies from 1,200 to $2,000 \mathrm{~mm}$, concentrated from October to March, and mean annual temperature lies around $24.6^{\circ} \mathrm{C}$ (Ramos-Neto and Pivello, 2000). Three quarters of ENP consist of flat tableland 820-888 $\mathrm{m}$ a.s.l., and the remaining area consists of hilly terrains $720-820 \mathrm{~m}$ a.s.1.

The cerrado in ENP has almost all physiognomies found in this vegetation type, from campo limpo (a grassland) to cerrado sensu stricto (a woodland). In the reserve, open cerrado physiognomies campo limpo, campo sujo (a shrub savanna), and campo cerrado (a savanna woodland) - prevail and cover $68.1 \%$ of the total area, especially on the flat tablelands (Ramos-Neto and Pivello, 2000). The more closed cerrado sensu stricto covers $25.1 \%$ of the reserve, mainly on the hilly terrain. Other vegetation types, such as floodplain grassland (4.9\% of the total area) and riparian or seasonal semideciduous forests $(1.2 \%)$, also exist within the park. Roads, firebreaks, and physical installations occupy the remaining $0.7 \%$.

We carried out a floristic survey in all cerrado physiognomies occurring within the reserve, from November 1998 to October 1999, in monthly field trips. In each one of them, the sampling effort varied from 50 to 60 hours. We identified the collected material to species level by comparing it to lodged vouchers and consulting taxonomic references. The identified specimens were then sent to taxonomists for confirmation. The voucher material was lodged mainly in the São Paulo State Botanical Institute herbarium.

We classified the species in families according to the system proposed by Judd et al. (2002) and in life-forms following Raunkiaer's (1934) system adapted by Mueller-Dombois and Ellenberg (1974). We considered the chamaephytes, epiphytes, hemicryptophytes, geophytes, lianas, vascular parasites, and therophytes as belonging to the herbaceous component, and the phanerophytes as belonging to the woody component. We used the terms "monospecific family" and "monospecific genus" according to Turner (1994), that is, families and genera with only one species in a given flora.

For both components of the cerrado flora, we computed the frequency distribution of species per family. We compared ENP with outlying cerrado sites in which both herbaceous and woody components were sampled: Mojiguaçu (Mantovani and Martins, 1993), Pirassununga (Batalha et al., 1997), and Santa Rita do Passa Quatro (Batalha and Mantovani, 2000), all located in the southeastern São Paulo State. We calculated the similarity values among these four sites with Sørensen index (Magurran, 1988).

To determine which families characterize each site, we used the Principal Component Analysis (PCA) (Jongman et al., 1995). In this case, we included only those families with at least ten species in one of the sites. Including only the richest families in the PCA reduces bias in the analysis (Gauch, 1982). If we had included all the families, our matrix would have many zeros and low values, which could mask the patterns we were interested in. Thus, selecting the ten richest families comprises most of the species and reduces bias in the analyses. Data were standardized and centralized before the analysis (Jongman et al., 1995).

To compare the distribution of woody species per family in ENP and in the whole cerrado, we reclassified the checklist compiled by Castro et al. (1999) according to Judd et al.'s (2002) system. We considered only those species identified with confidence, that is, those species identified dubiously (aff. or cf.) or only to genus or family level were not included in our analysis. We selected the ten richest families of each flora to carry out the comparison. Even if one of the richest families in a flora was not among the richest families in the other, it was included in the analysis. For example, Euphorbiaceae, which was one of the richest families in the woody component of the cerrado as a whole but not in ENP, was included in the analysis. Floristic surveys in the cerrado have shown that its flora is characterized by few families with a great number of species and by many families with only one species (e.g., Mantovani and Martins, 1993; Batalha et al., 1997; Castro et al., 1999; Batalha and Mantovani, 2001). Thus, selecting the ten richest families comprises most of the species and reduces bias in the analyses (Gauch, 1982).

We constructed a contingency table and compared the frequency distributions in ENP and in the 
cerrado as a whole by means of the chi-square test (Zar, 1999). Similarly, we compared the distribution of herbaceous species per family in ENP and in the whole cerrado (Batalha, 2001) using the ten richest families of each list. To verify whether these two distributions were significantly different, we arranged the data in a contingency table and applied the chi-square test (Zar, 1999).

\section{RESULTS}

In our floristic survey of the ENP, we found 601 species, 303 genera, and 80 families. Among these 601 species, we considered 149 as belonging to the woody component and 452 , to the herbaceous component. The richest families were, on decreasing order, Asteraceae (88 species), Fabaceae (87), Poaceae (51), Myrtaceae (39), Lamiaceae (24), Malpighiaceae (23), Euphorbiaceae (20), Apocynaceae (19), Malvaceae (16), and Rubiaceae (16), which represented $63.73 \%$ of the total number of species in ENP.

In the woody component, the richest families were Fabaceae (28 species), Myrtaceae (23), Malpighiaceae (7), Melastomataceae (7), Annonaceae (6), Apocynaceae (5), Vochysiaceae (5), Bignoniaceae (4), Nyctaginaceae (4), and Rubiaceae (4), which together accounted for
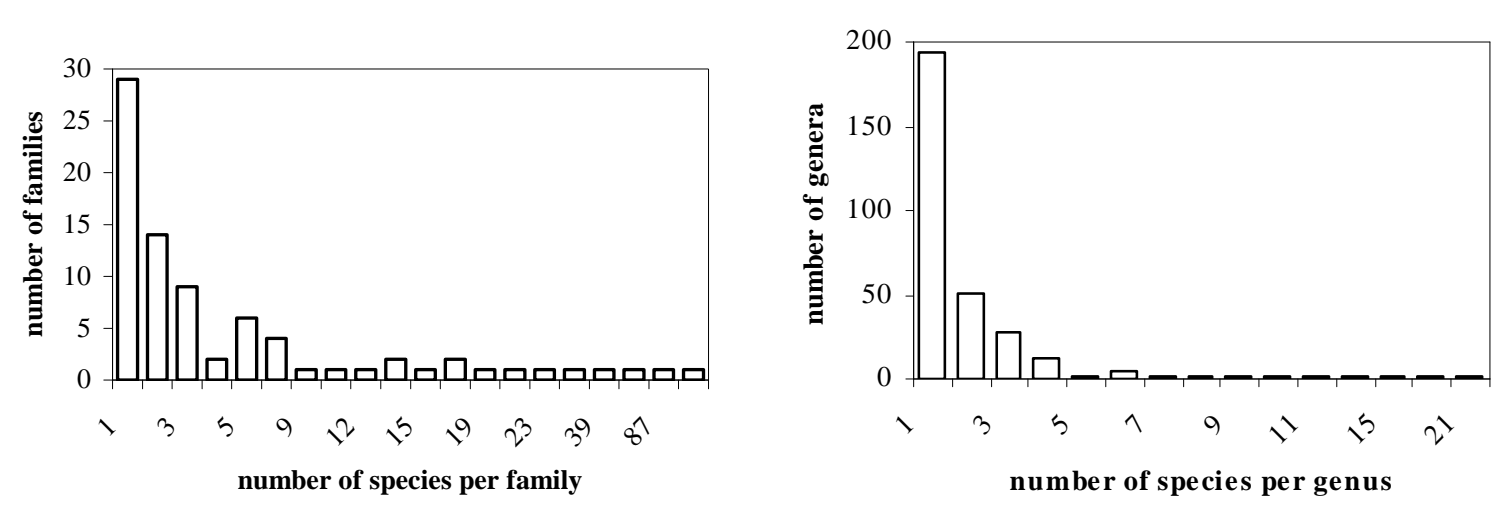

Figure 2 - Frequency distribution of family and genus sizes in the cerrado vascular flora of Emas

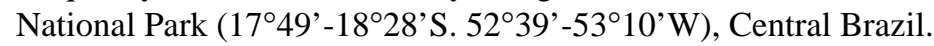

$62.42 \%$ of the woody species in ENP. In the herbaceous component, the richest families were Asteraceae (83 species), Fabaceae (59), Poaceae (48), Lamiaceae (23), Euphorbiaceae (19), Malpighiaceae (16), Myrtaceae (16), Convolvulaceae (15), Apocynaceae (14), and Malvaceae (13), which comprised $68.14 \%$ of the herbaceous species in ENP. The ENP's flora presented a highly skewed frequency distribution to the smallest size class of both species per family and species per genus (Fig. 2), with one being the modal class for both distributions. Monospecific families made up $36.25 \%$ of the total families, and monospecific genera, $64.03 \%$ of the total genera. The similarity values (Table 1 ) between ENP and the outlying cerrado sites ranged from 0.413 (ENP vs. Pirassununga) to 0.441 (ENP vs. Santa Rita do Passa Quatro). These numbers were higher among the outlying sites, Pirassununga and Santa Rita do Passa Quatro being the most similar ones (0.660). The first axis of the PCA (Fig.3) explained $54.06 \%$ of the variation, and the second axis, an additional $34.91 \%$. The first axis separated the ENP from the outlying cerrado sites, the former with positive scores and the latter with negative scores. The families with higher positive scores in the first axis were Convolvulaceae and Lamiaceae, and the families with higher negative scores were Melastomataceae and Rubiaceae. 


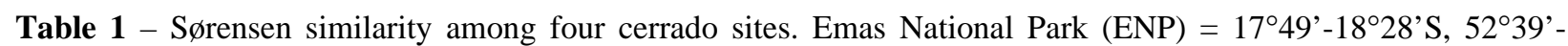
$53^{\circ} 10^{\prime} \mathrm{W}$; Mojiguaçu (Moji) $=22^{\circ} 15-16^{\prime} \mathrm{S}, 4^{\circ} 08-12^{\prime} \mathrm{W}$; Pirassununga (Pira) $=22^{\circ} 02^{\prime} \mathrm{S}, 4^{\circ} 30^{\prime} \mathrm{W}$; Santa Rita do Passa Quatro $(\mathrm{SR})=21^{\circ} 36-44^{\prime} \mathrm{S}, 47^{\circ} 34-41^{\prime} \mathrm{W}$.

\begin{tabular}{lllll}
\hline & ENP & Moji & Pira & SR \\
\hline ENP & 1.000 & & & \\
Moji & 0.426 & 1.000 & 1.000 & 1.000 \\
Pira & 0.413 & 0.629 & 0.660 & \\
SR & 0.441 & 0.559 & & \\
\hline
\end{tabular}

The distribution of species per family in the woody component was significantly different between the ENP and the whole cerrado $\left(\chi^{2}=\right.$ 28.79, $P=0.004)$, due especially to an overproportion of Myrtaceae $(41.73 \%$ of the chisquare value) and Nyctaginaceae $(21.83 \%)$ and an underproportion of Asteraceae (12.59\%) in ENP's woody flora (Table 2). Among the most constant species in cerrado samples, i.e., those appearing on at least $50 \%$ of the sites related by Ratter et al. (2003), we did not find only Astronium fraxinifolium Schott, Curatella americana L., Ouratea hexasperma (A. St-Hil.) Benth., Salvertia convallariodora A. St-Hil., and Sclerolobium aureum (Tul.) Benth. in ENP.

Seventeen out of the 149 woody species (11.4\%) did not appear on the checklist of the cerrado woody flora established by Castro et al. (1999): Annona sp. nov., Aiouea trinervis Meisn., Apoclada arenicola McClure, Banisteriopsis acerosa (Nied.) B. Gates, Calliandra macrocalyx
Harms, Dalbergia cuiabensis Benth., Mimosa amnis-atri Barneby, M. gemmulata Barneby, $M$. hebecarpa Benth., Myrcia bracteata O. Berg, M. camapuanensis N.F.E. Silveira, M. crassifolia (O. Berg) Kiaersk., M. fallax (Rich.) A. DC., M. linguaeformis Kiaersk., M. rhodeosepala Kiaersk., Olyra taquara Sw., and Psidium laruotteanum Cambess. Out of these, A. trinervis, D. cuiabensis, $M$. hebecarpa, $M$. camapuanensis, and $M$. rhodeosepala were included in the checklist compiled by Ratter et al. (2003).

The frequency distribution of species per family in the herbaceous component was also significantly different between the ENP and the whole cerrado $\left(\chi^{2}=53.15, P<0.001\right)$ due mainly to an overproportion of Myrtaceae in ENP, which was responsible for $41.84 \%$ of the chi-square value (Table 3). In relation to the whole cerrado, Lythraceae (13.42\% of the chi-square value) and Orchidaceae $(12.87 \%)$ presented a frequency lower than expected in ENP's herbaceous flora.

Table 2 - Number of woody species per family in Emas National Park (ENP) and in the whole cerrado. Expected number of species in ENP were calculated with the proportions observed in the cerrado as a whole (Castro et al., 1999). Family names were abbreviated according to Weber (1982).

\begin{tabular}{|c|c|c|c|}
\hline \multirow[b]{3}{*}{ Family } & \multicolumn{3}{|c|}{ number of woody species } \\
\hline & \multicolumn{2}{|c|}{ ENP } & \multirow{2}{*}{$\begin{array}{c}\text { whole cerrado } \\
\text { observed } \\
\end{array}$} \\
\hline & observed & expected & \\
\hline Fab & 28 & 26.65 & 174 \\
\hline Mrt & 23 & 11.33 & 74 \\
\hline Mlp & 7 & 7.35 & 48 \\
\hline Mls & 7 & 8.12 & 53 \\
\hline Ann & 6 & 3.98 & 26 \\
\hline Apo & 5 & 3.22 & 21 \\
\hline Voc & 5 & 3.68 & 24 \\
\hline Big & 4 & 5.36 & 35 \\
\hline Nyc & 4 & 1.23 & 8 \\
\hline Rub & 4 & 6.43 & 42 \\
\hline Ast & 3 & 8.58 & 56 \\
\hline Eup & 1 & 3.68 & 24 \\
\hline Others & 52 & 59.42 & 388 \\
\hline
\end{tabular}




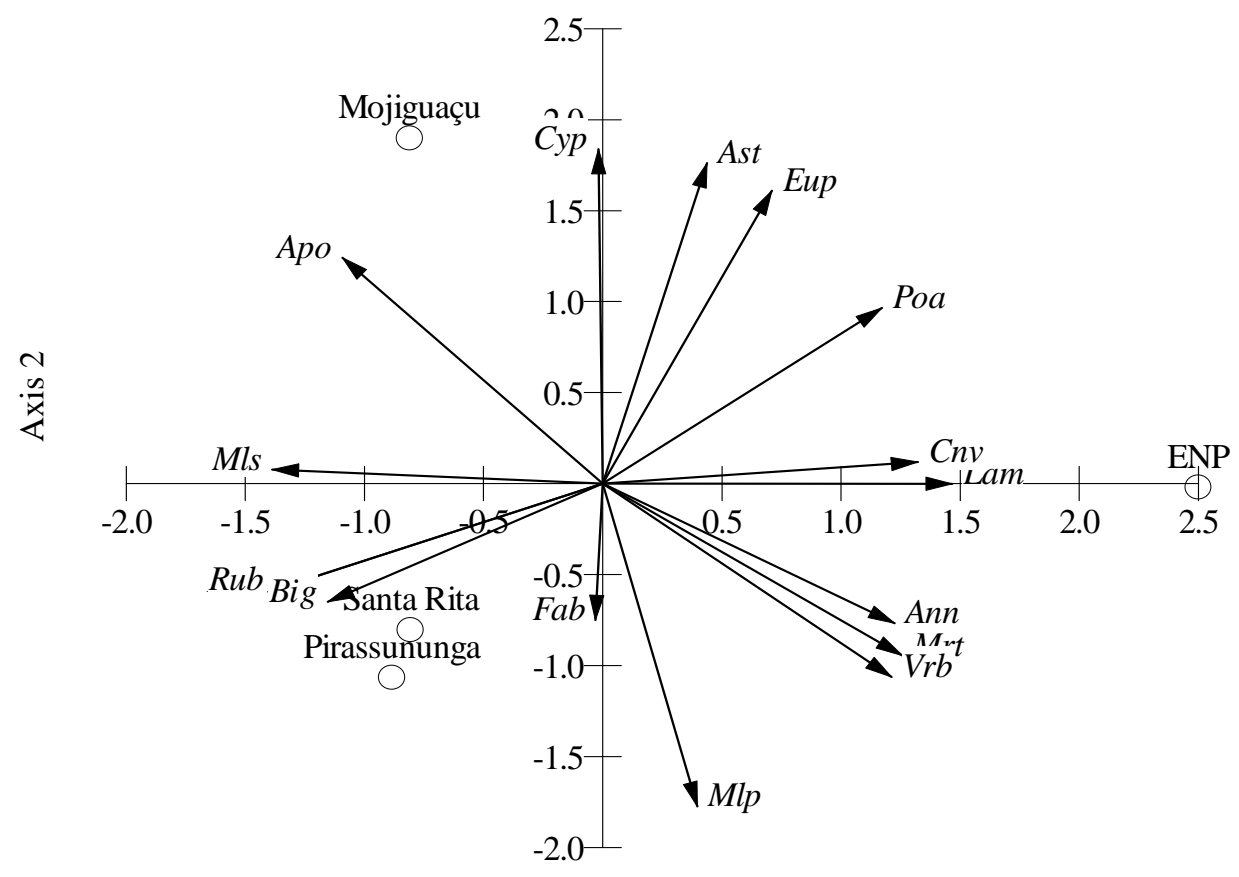

Axis 1

Vector scaling: 4.44

Figure 3 - Principal component analysis biplot of the richest families in four cerrado floras. ENP (Emas National Park) $=17^{\circ} 49^{\prime}-18^{\circ} 28^{\prime} \mathrm{S}$. 52 $2^{\circ} 39^{\prime}-53^{\circ} 10^{\prime} \mathrm{W}$; Mojiguaçu = $22^{\circ} 15-16^{\prime}$ S. $47^{\circ} 08-12^{\prime} \mathrm{W}$; Pirassununga $=22^{\circ} 02^{\prime}$ S. $47^{\circ} 30^{\prime} \mathrm{W}$; Santa Rita (Santa Rita do Passa Quatro) $=21^{\circ} 36-44^{\prime}$ S. $47^{\circ} 34-41^{\prime} \mathrm{W}$. Family names were abbreviated according to Weber (1982).

Table 3 - Number of herbaceous species per family in Emas National Park (ENP) and in the whole cerrado. Expected number of species in ENP were calculated with the proportions observed in the cerrado as a whole (Batalha, 2001). Family names were abbreviated according to Weber (1982).

\begin{tabular}{|c|c|c|c|}
\hline \multirow[b]{3}{*}{ Family } & \multicolumn{2}{|c|}{ Number of herbaceous species } & \multirow[b]{2}{*}{ whole cerrado } \\
\hline & & & \\
\hline & observed & expected & observed \\
\hline Ast & 85 & 70.27 & 444 \\
\hline $\mathrm{Fab}$ & 59 & 58.56 & 370 \\
\hline Poa & 48 & 41.62 & 263 \\
\hline Lam & 23 & 20.26 & 128 \\
\hline Eup & 19 & 20.10 & 127 \\
\hline Mlp & 16 & 10.76 & 68 \\
\hline Mrt & 16 & 5.22 & 33 \\
\hline Cnv & 15 & 13.77 & 87 \\
\hline Apo & 14 & 12.82 & 81 \\
\hline Mlv & 13 & 13.93 & 88 \\
\hline Сур & 12 & 7.75 & 49 \\
\hline Rub & 12 & 15.67 & 99 \\
\hline Vrb & 12 & 8.70 & 55 \\
\hline Orc & 5 & 15.19 & 96 \\
\hline Lyt & 2 & 10.76 & 68 \\
\hline Others & 101 & 126.61 & 800 \\
\hline
\end{tabular}




\section{DISCUSSION}

Considering that the number of angiosperm species in the cerrado vegetation ranges from 3,000 to 7,000 (Castro et al., 1999), then ENP comprises from 8.5 to $20.0 \%$ of the cerrado flora, approximately. These numbers alone are enough to show the importance of ENP for the conservation of the cerrado vegetation. It is very rare to find over 100 woody species in any community (Ratter et al., 2003). The 149 woody species found in ENP also highlights the importance of ENP for the cerrado conservation. The number of species in ENP may be increased by species not found in this survey, since floristic surveys certainly miss a number of species in a given area, especially those that are not at reproductive stage by the time of the visit, flower sporadically, are ephemeral, or are inconspicuous (Castro et al., 1999).

The distribution of species per family and genus was highly skewed in ENP's flora, with many monospecific families and genera, the same pattern found in the cerrado as a whole (Castro et al., 1999; Ratter et al., 2003). If the proportion of monospecific families and genera in the cerrado were high, then these monospecific taxa would have great influence on the similarity among cerrado sites. If the geographic range of these monospecific taxa were small, then the similarity values should be low; but, if their geographic range were large, then the similarity values should be high. Low similarity values and high proportions of monospecific taxa would corroborate the high degree of endemism and narrow geographic range of the cerrado species (Castro et al., 1999; Ratter et al., 2003). Consequently, we expect a negative correlation between geographic distance and similarity values among cerrado sites.

Although the similarity values were relatively high (Mueller-Dombois and Ellenberg, 1974), the similarity values between ENP, a core cerrado site, and the southeastern outlying cerrados were lower than the similarity values among these outlying sites, probably as a consequence of the greater geographic distance. The number of species in the sites under comparison influenced Sørensen index, but, regardless of the richness of each site, the similarity values between ENP and the outlying sites were always lower than among the outlying sites. Comparisons of different cerrado sites have shown that their floristic composition may vary widely even among geographically close sites, and that many species have sporadic or patchy distributions (Castro et al., 1999; Ratter et al., 2003). Even if this comparison is restricted to few sites due to the almost complete absence of studies sampling both herbaceous and woody components, a geographic pattern in the floristic composition of cerrado sites seems to exist when both components are considered, even when all sites are in the same sector - in this case, the $P$. rotundifolia sector.

The first PCA axis was enough to separate clearly the ENP from the outlying sites, suggesting that there could also be differences on family level between core and outlying sites. This analysis indicated that ENP was characterized by Convolvulaceae and Lamiaceae and the outlying sites, by Melastomataceae and Rubiaceae. When more floristic surveys considering both woody and herbaceous components are available, this pattern should be tested for its consistency.

In the woody component, the frequency distribution of species per family in ENP was significantly different from those found in the whole cerrado (Castro et al., 1999), being characterized by a higher proportion of Myrtaceae and Nyctaginaceae and a lower proportion of Asteraceae in ENP. In the checklist compiled for the whole cerrado (Castro et al., 1999), the high proportion of undetermined taxa in some families may alter the frequency distribution of family sizes. For example, in addition to the 96 species belonging to Myrtaceae, there are more 100 taxa not identified with confidence in this family (Castro et al., 1999).

Another bias in this comparison is the different criteria adopted to consider a given species as belonging to the woody component. While we considered only the phanerophytes as woody species, Castro et al. (1999) used as many criteria as appeared in the surveys they compiled, i.e., for them, if only one author considered a certain species as woody, it was included in their list. Many Asteraceae species included in their list are not phanerophytes and, thus, if they occurred in ENP, we did not consider them as belonging to the woody component. This could explain the underproportion of this family in ENP when compared with the cerrado as a whole.

Amongst the most constant species in cerrado sites (Ratter et al., 2003), those not found in ENP, Astronium fraxinifolium, Curatella americana, Ouratea hexasperma, Salvertia convallariodora, 
and Sclerolobium aureum occurred preferentially in other phytogeographic groups. The 17 species found in this survey that should be included in Castro's et al. (1999) list and the 12 species that should be included in Ratter's et al. (2003) list represented a high percentage of the species collected in ENP and indicated that even the woody component of the cerrado vegetation remains undercollected.

In the herbaceous component, the frequency distribution of species per family in ENP was also significantly different from that found in the whole cerrado (Batalha, 2001). The herbaceous component in ENP's flora was also characterized by a higher proportion of Myrtaceae. The underproportion of Orchidaceae and Lythraceae in ENP could be a consequence of many species with small geographic range, that is, they could be families with many species with restricted geographic range and therefore appearing with many species only when one was working on larger scales. Therefore, the geographic patterns found by Castro et al. (1999) and Ratter et al. (1996; 2003) for the cerrado woody species could exist for the herbaceous species as well, which can be tested only when more surveys in this component are available.

Although both herbaceous and woody components of ENP's cerrado flora presented significantly different distribution of family sizes when compared with the whole cerrado, the chi-square value was much higher in the herbaceous component. This corroborated the hypothesis that the heterogeneity - in this case, the frequency distribution of family sizes - was much higher in the herbaceous than in the woody component of the cerrado flora (Castro et al., 1999).

The flora of the cerrado in ENP presented the same pattern found in the whole cerrado concerning the frequency distribution of family and genus sizes, that is, highly skewed to the smallest class. The distribution of species per family for the whole cerrado may be used as a null model, against which the flora of a particular site may be tested. In ENP, we found some families that characterized its flora in relation to the distribution found for the whole cerrado. These comparisons should be carried out for other sites, trying to find out whether there is a geographic or even a physiognomic pattern in the frequency distribution of species per family in the cerrado. The geographic pattern of the cerrado flora seems to exist both for family and genus levels. Some families would then characterize some phytogeographical groups. However, up to now there are few surveys in which both components of the cerrado flora, and not only the woody component, were sampled. When more complete lists are available, the consistency of the patterns found in ENP in relation to the whole cerrado may be tested.

\section{ACKNOWLEDGEMENTS}

We are grateful to Fapesp for financial support, to Ibama for research license, to the Emas National Park staff for their help in field, and to M.B. Ramos-Neto for logistical assistance.

\section{RESUMO}

O cerrado pode ser dividido em dois principais setores fitogeográficos: um caracterizado por Piptocarpha rotundifolia, em que o Parque Nacional das Emas (PNE) está localizado, e outro caracterizado por Curatella americana. Realizamos um levantamento florístico no PNE, que nos permitiu determinar a composição taxonômica de sua flora vascular e sua similaridade com outros sítios. Comparamos a flora do PNE com sítios disjuntos de cerrado, também no setor Piptocarpha, e com padrões florísticos gerais do cerrado. A distribuição de espécies por família foi significativamente diferente daquela obtida para cada componente da flora do cerrado. O componente herbáceosubarbustivo se caracterizou pela superrepresentação de Myrtaceae e pela subrepresentação de Orchidaceae e Lythraceae; e o componente arbustivo-arbóreo, pela superrepresentação de Myrtaceae e Nyctaginaceae. Quando comparado aos sítios disjuntos, o PNE se mostrou distinto, não só em nível específico, mas também em nível de famílias.

\section{REFERENCES}

Batalha, M. A. (2001), Florística, espectro biológico e padrões fenológicos do cerrado sensu lato no Parque Nacional das Emas (GO) e o componente herbáceosubarbustivo da flora do cerrado sensu lato. $\mathrm{PhD}$ Thesis, State University of Campinas, Campinas, Brazil. 
Batalha, M. A.; Aragaki, S. and Mantovani, W. (1997), Florística do cerrado em Emas (Pirassununga, SP). Bolm. Bot. Univ. S. Paulo, 16, 49-64.

Batalha, M. A. and Mantovani, W. (2000), Reproductive phenological patterns of cerrado plant species at the Pé-de-Gigante Reserve (Santa Rita do Passa Quatro, SP, Brazil): a comparison between the herbaceous and the woody floras. Braz. J. Biol., 60, 129-145.

Batalha, M. A. and Mantovani, W. (2001), Floristic composition of the cerrado in the Pé-de-Gigante Reserve (Santa Rita do Passa Quatro, southeastern Brazil). Acta Bot. Bras., 15, 147-163.

Batalha, M. A. and Martins, F. R. (2002), The vascular flora of the cerrado in Emas National Park (Goiás, central Brazil). Sida, 20, 295-312.

Castro, A. A. J. F. (1994), Comparação florísticageográfica (Brasil) e fitossociológica (Piauí - São Paulo) de amostras de cerrado. PhD Thesis, State University of Campinas, Campinas, Brazil.

Castro, A. A. J. F.; Martins, F. R.; Tamashiro, J. Y. and Shepherd, G. J. (1999), How rich is the flora of the Brazilian cerrados? Ann. Miss. Bot. Gard., 86, 192224.

Coutinho, L. M. (1990), Fire in the ecology of the Brazilian cerrado. In - Fire in the tropical biota, ed. J. G. Goldammer. Springer, Berlin, pp. 81-105.

Fonseca, G. A. B.; Mittermeier, R. A.; Cavalcanti, R. B. and Mittermeier, C.G. (2000), Brazilian Cerrado. In Hotspots, Earth's biologically richest and most endangered terrestrial ecoregions, eds. R. A. Mittermeier, N. Myers, P. R. Gil and C. G. Mittermeier. Conservation International, Chicago, pp. 148-159.

Gauch, H. G. (1982), Multivariate analysis in community ecology. Cambridge University, Cambridge.

Jongman, R. H. G.; Ter Braak, C. J. F. and Van Tongeren, O. F. R. (1995), Data analysis in community and landscape ecology. Cambridge University, Cambridge.

Judd, W. S.; Campbell, C. S.; Kellog, E. A. and Stevens, P. F. (2002), Plant systematics: a phylogenetic approach. Sinauer, Sunderland.

Köppen, W. (1931), Grundriss der Klimakunde. Gruyter, Berlin.
Magurran, A. E. (1988), Ecological diversity and its measurement. Princeton University, Princeton.

Mantovani, W. and Martins, F. R. (1993), Florística do cerrado na reserva biológica de Moji Guaçu, SP. Acta Bot. Bras., 7, 33-60.

Mueller-Dombois, D. and Ellenber, H (1974), Aims and methods of Vegetation Ecology. John Willey and Sons, New York.

Ramos-Neto, M. B. and Pivello, V. R. (2000), Lightning fires in a Brazilian savanna National Park: rethinking management strategies. Environ. Manag., 26, 675-684.

Ratter, J. A.; Bridgewater, S.; Atkinson, R. and Ribeiro, J. F. (1996), An analysis of the floristic composition of the Brazilian cerrado vegetation II: comparison of the woody vegetation of 98 areas. Edinb. J. Bot., 53, 153-180.

Ratter, J. A.; Ribeiro, J. F. and Bridgewater, S. (1997), The Brazilian cerrado vegetation and threats to its biodiversity. Ann. Bot., 80, 223-230.

Ratter, J. A.; Bridgewater, S. and Ribeiro, J. F. (2003), An analysis of the floristic composition of the Brazilian cerrado vegetation III: comparison of the woody vegetation of 376 areas. Edinb. J. Bot., 60, 57109.

Raunkiaer, C. (1934), The life forms of plants and statistical geography. Claredon, Oxford.

Sarmiento, G. (1983), The savannas of Tropical America. In - Ecosystems of the world - tropical savannas, ed. D. W. Goodall. Elsevier, Amsterdam, pp. 245-288.

Turner, I. M. (1994), The taxonomy and ecology of the vascular plant flora of Singapore: a statistical analysis. Bot. J. Linn. Soc., 114, 215-227.

Unesco. (2001), Cerrado protected areas: Chapada dos Veadeiros and Emas National Parks. Paris, Unesco. http://www.unesco.org/whc/sites/1035.htm.

Weber, W. A. (1982), Mnemonic three-letter acronyms for the families of vascular plants: a device for more effective herbarium curation. Taxon, 31, 74-88.

Zar, J.H. (1999), Biostatiscal analysis. Prentice Hall, Upper Saddle River. 
PÁGINA

EM

BRANCO 